\title{
Richard Rorty Contra Rorty and John Dewey
}

Joseph Margolis

\section{OpenEdition}

\section{Journals}

Electronic version

URL: http://journals.openedition.org/ejpap/308

DOI: 10.4000/ejpap.308

ISSN: 2036-4091

\section{Publisher}

Associazione Pragma

\section{Electronic reference}

Joseph Margolis, «Richard Rorty Contra Rorty and John Dewey », European Journal of Pragmatism and American Philosophy [Online], VI-2 | 2014, Online since 24 December 2014, connection on 19 April 2019. URL : http://journals.openedition.org/ejpap/308 ; DOI : 10.4000/ejpap.308

\section{(c) $\underset{\mathrm{EY}}{(\mathrm{NO})} \mathrm{\Theta O}$}

Author retains copyright and grants the European Journal of Pragmatism and American Philosophy right of first publication with the work simultaneously licensed under a Creative Commons AttributionNonCommercial-NoDerivatives 4.0 International License. 


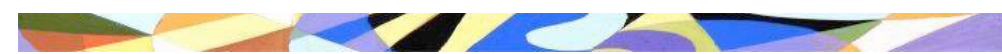

EUROPEAN JOURNAL OF PRAGMATISM AND AMERICAN PHILOSOPHY

COPYRIGHT C 2009 ASSOCIAZIONE PRAGMA

Joseph Margolis*

Richard Rorty Contra Rorty and John Dewey

Abstract: Dewey's concept of “experience" has baffled many a reader. It is, however, assuredly the key to Dewey's distinctive philosophical contribution. Notoriously, Rorty urges that Dewey would have been well-advised to abandon "experience: in favor of "discourse" (that is, the "linguistic method of philosophy"), which he draws largely from Davidson and Sellars. For various reasons, Rorty betrays his deep misunderstanding of Dewey's pragmatism, the lack of any close relationship between Sellars's notion of the "given" (as a philosophical target) and Dewey's notion of the saving discovery of what is "denoted" (in inquiry) as the "given"; and the extremely problematic (possibly even incoherent) treatment of linguistic meaning in Davidson's most pertinent papers (which Rorty seems to regard as pragmatist in an important sense and is guided by). In any event, neither Davidson nor Rorty can be rightly supposed to extend or improve Deweyan pragmatism: Rorty, in fact, explicitly and unconditionally repudiates the "linguistic turn"; and Davidson finally subverts the very theory of language on which any reading of Rorty's "pragmatist" account of Davidson's theory of meaning would be at all feasible. The exposé of these disorders may contributes to a more careful formulation of the pragmatist undertaking, which lies elsewhere and depends on a measure of convergence between Dewey and Peirce.

\section{$I$}

The opening chapters of John Dewey's Logic and Experience and Nature are, arguably, the most important and strategic of Dewey's entire output: the first chapter of the Logic is baffling and the matching chapter of Experience and Nature, meant, plausibly, to range over the same conceptual terrain, is hard to reconcile, textually, with its companion in the Logic. Notoriously, Richard Rorty, who claims to be an admirer of Dewey's, reads Experience and Nature as confirming that there's no need for any metaphysics, and, against both books, advises that Dewey should have rejected the primacy of his doctrine of "experience" (which draws courage from William James's remarkably expansive use of the same concept, in Essays in Radical Empiricism), and should have relied instead on linguistically explicit propositions ("discourse"), which strikes me as incoherent. The most sustained - oblique - version of Rorty’s argument appears in Philosophy and the Mirror of Nature; a narrower argument, specifically directed against Dewey's metaphysics and epistemology in Experience and Nature, appears in Rorty's "Dewey's Metaphysics".

\footnotetext{
* Temple University [josephmargolis455@hotmail.com]

1. See Rorty (1979: Introduction and Part Three); and Rorty (1982: "Dewey’s Metaphysics"). See, also, the well-known second sentence (regarding "experience") in "Inquiry as recontextualization: An anti-dualist account of interpretation", in Rorty (1991: 93). (The essay seems to have been written in, or somewhat before, 1988.)
} 
But, to my mind, it's Rorty's failure to engage Dewey's account of "experience" (in the Logic) - an admittedly exotic, idiosyncratic, blunderbuss of a notion - and his failure to examine the common ground of the opening chapters of the two books, with regard to their shared theme, that is more troublesome. Because, lacking such an effort, Rorty's advice is never really grounded pertinently - and must seem, to any ordinarily careful reader, to be completely wide of the mark and (as I say) incoherent on its face.

I'm not persuaded that Dewey's account in the Logic (or what of it is implicated in the first chapter of Experience and Nature) is entirely felicitous - or compelling; although its thrust and originality are straightforward enough and relatively uncontroversial (once rightly grasped). It's not an easy task, however, to render a transparent formula of what Dewey means by "experience", "metaphysics", and "the method of denoting", by the use of which he circumscribes his undertaking. The best brief statement of Dewey's metaphysics, which Rorty cites (which Arthur Murphy had already cited in his contribution to the Schilpp volume) runs this way:

This is the extent and method of my metaphysics [Dewey affirms, in an earlier paper]: the large and constant features of human sufferings, enjoyments, trials, failures and successes together with the institutions of art, science, technology, politics and religion which mark them, communicate genuine features of the world within which man lives. ${ }^{2}$

Murphy rightly thinks this "method" (said to be "empirical" or responsive to "experience") is not likely "to provide the "final explanation' or 'a unique approach to reality"' (Murphy 1951: 218). But then Murphy actually seems to favor Dewey's avoidance of an ultimate metaphysics: Dewey positively wants a blunderbuss solution, though an answer grounded at both ends of an "inquiry", so to say - that is, "denotatively" and in terms of scientific testing, in any pertinently initial "experience" and in any subsequent interpretation of it that we undertake. Whatever bears on human life (in this sense) is welcome, since it is as reliably "given", discerned, or "denoted" in any humanly inhabited world, as anything claiming evidential standing:

Man fears because he exists in a fearful, an awful world. The world is precarious and perilous. It is as easily accessible and striking evidence of this fact that primitive experience is cited. The voice is that of early man; but the hand is that of nature, the nature in which we still live. (Dewey 1981: 43-4)

The traits possessed by the subject-matters of experience are as genuine as the characteristics of sun and electron. They are found, experienced, and are not to be shoved out of being by some trick of logic. When found, their ideal qualities are as relevant to the philosophical theory of nature as are the traits found by physical inquiry. (Dewey 1981: 14)

As far as I can see, Dewey simply means to feature, in the most informal and tolerant way, the continuity and contrast between what he calls "gross, macroscopic,

2. Dewey, "Half-Hearted Naturalism" (1927: 59); cited in Murphy, "Dewey’s Epistemology and Metaphysics", in Schilpp (1951: 217); and in Rorty's "Dewey’s Metaphysics" (1982: 73). 
crude subject-matters in primary experience and the refined, derived objects of [scientific and technical] reflection" (Dewey 1981: $15 \mathrm{ff}$.). It also explains the otherwise puzzling account of (what he calls) "inquiry" (in the Logic) and the features of an "indeterminate situation"(Dewey 1938: 104-5). Dewey simply ascribes ("mythically", let us say) psychological and anthropomorphized properties to bio-cultural, holist, even precognitive "situations" in which specifically human interests and responses are said to take form from initially inchoate organismic processes, in which the familiar determinacies of subjective and objective presence and functionality cannot yet be posited. The principal purpose of this way of speaking is, apparently, to insure (awkwardly, it must be said) the reality of the human world at its most elemental ("primary experience"); the characterization of the language of determinate subjects and objects as thoroughly (but never more than) instrumental and provisional, apt for the resolution of diverse and adventitious goals; and, also, the continuum of the world shared by "primary experience" and a disciplined science.

What Dewey says here is remarkably unguarded. He treats the "macroscopic" order of human "sufferings [and] enjoyments" as "given" ("denoted"), without any need for fine-grained confirmation beyond the "crude" determinacies of what creatures endure ("find") in "primary experience" (which may, in fact, depend as much on noncognitive [sic] as on cognized "experience"). Dewey's insistence is meant to be existential, in the sense in which, regarding primary experience, there can be no tribunal but the testimony of the human creature that endures - and that confirms the pertinence of whatever is judged to serve as the resolution of a risked "inquiry": the outcome, beyond the precision of any mediating science, cannot be more than "warrantedly assertible". ("True" is itself restricted to whatever plays no more than a mediating role.) Note, please, that metaphysics and epistemology must, then, trail off into the vagaries of organismic life: the precision of logic and science is itself no more than approximative and informal, being instrumental finally to the transient goals of the same inquiry that invites their subaltern precision. I venture to say that Rorty has no inkling of such innovations - and no interest in their philosophical possibilities. But it is indeed this slim discovery that I deem houses the best prophecy about pragmatism's larger prospects within the future of Western philosophy.

One may be pardoned, therefore, if one finds oneself bewildered by Rorty's apparent effort to defeat or deform any plausible reading of Dewey's undertaking. We cannot easily say (if we accept Rorty's loose charges) what we should understand by the philosophical program or movement called "pragmatism"; or what Dewey may be rightly said to have accomplished; or indeed in what sense figures like Heidegger, Wittgenstein, Davidson, Wilfrid Sellars and Robert Brandom may (or may not) be reasonably regarded as pragmatists themselves, in the strongest possible sense of the term - especially when judged with an eye to the movement's future and in accord with Rorty's habit of regarding these somewhat unlikely figures (and a good many others whom he mentions) as distinctly potent pragmatists ${ }^{3}$.

3. See, for instance, the figures Rorty collects as "pragmatists" in Philosophy and the Mirror of Nature, "Introduction" and Chapter 7. 
My charge against Rorty, quite simply, is that his dismissive judgments are often irresponsible (if we credit Dewey's bona fides at all) or, worse, are no more than potted versions of his dismissal of canonical philosophy itself. The fact remains that Dewey never intended to reject metaphysics or epistemology (as Rorty more than insinuates) and that, at the same time - to judge, hardly unfairly, from what I've already cited Dewey's pronouncements on both disciplines are meant to assign them no more than an instrumental, provisionally mediating role within the span of inquiry itself, within the approximate boundaries of "indeterminate" and "determinate" situations. I think this is characteristic of Dewey's opposition to canonical (so-called "spectatorial") philosophy (prone to generating telltale "dualisms") and his treatment of the otherwise puzzling priorities involving the division of labor (central to the Logic) of the eminent functions of those strategically contrasted terms, "truth" and "warranted assertibility" - assigning primacy to the latter (in the instrumental judgments of a running inquiry) over "truth" (restricted to the seeming invariances of propositionalized assertions serving conventional logic and conventional science). This is the obvious point of the well-known remark, near the beginning of the Logic:

The theory [of Logic], in summary form, is that all logical forms (with their characteristic properties) arise within the operation of inquiry and are concerned with control of inquiry so that it may yield warranted assertions...Inquiry is the life-blood of every science and is constantly employed in every art, craft and profession. In short, the hypothesis represents a vera causa, no matter what doubt may attend its applicability in the field of logic. (Dewey 1938: 4)

Dewey's entire project is to embed the seemingly autonomous work of canonical logic and science completely, in the instrumentalist way, within the continuum of "inquiry" - in accord with the notorious, but now relatively straightforward precept (controversial, though it must remain):

Inquiry is the controlled or directed transformation of an indeterminate situation into one that is so determinate in its constituent distinctions and relations as to convert the elements of the original situation into a unified whole. (Dewey 1938: $104 \mathrm{ff}$.)

Now, then, "experience", in Dewey's usage (following James) applies in an unlimited variety of ways to every phase of "inquiry" thus construed: so that, for instance, it applies to "nature" as well as to "experience" (in any psychologistic or mentalistic or rationalist sense), and to nonconscious and "noncognitive" ("organismic", inchoate) forms of animal responsiveness as well as to the fully cognitive, discursive, deliberately "controlled" interventions of science.

Given Dewey's ingenious terms (sometimes awkwardly and less than helpfully expressed), this "empirical method" insures the essentially instrumental (or passingly adequate) standing of any would-be substantive metaphysics and epistemology, the effective "givenness" of "primary experience" (in some tolerant sense grounded in whatever we find effectively "denoted" within a "problematic situation"), however caught up, mediatingly, by the provisional fixities of canonical logic and science: 
themselves ultimately subject to being "tested" by returning to the now-transformed, derivative (but not formally inferred) "situation" in which the existential core concerns of humans are always first discerned. If this is a fair rendering of Dewey's thesis - say, the primacy of "warranted assertibility" over "truth" - then, certainly, Rorty is wildly off the mark in characterizing Dewey's pragmatism, as well as in characterizing pragmatism in the large (drawn, congruently, from all the classic figures). Here, my own interest in the agon has it that Rorty not only misreads Dewey, ignores the deeper, genuinely important convergence between Dewey and Charles Peirce, fails to see that the penetrating import of Dewey's application of James's suggestive (more than problematic) use of James's own notion of "experience" eclipses the oddly detached treatment of "experience" in Radical Empiricism. (The importance of James's intuition can only be recovered through a labor like Dewey's: James's contribution is, as we say, proleptic.)

But, now, on my reading, Dewey's contribution is itself distinctly supportive and supplementary to the dawning power of Peirce's last phase of philosophical invention - what I call Peirce's "abductive turn", which, in the last decade or so of Peirce's life, begins to replace (for pertinent reasons) Peirce's own, best known infinitist reading of his classic form of fallibilism. I'm quite convinced, now, that Peirce perseverated much too long with the infinitist doctrine, though he characteristically cast the thesis in the form of rational Hope, not truth, and not in any explicitly transcendental or apriorist way.

On the contrary, Peirce seems to have been opposed to Kant's apriorism almost from the beginning of his "career", possibly as early as 1859 but certainly already in the $1860 \mathrm{~s}^{4}$. Peirce says, quite marvelously, rather late in his career:

Kant (whom I more than admire) is nothing but a somewhat confused pragmatist. A real is anything that is not affected by men's cognitions about it; which is a verbal definition, not a doctrine. An external object is anything that is not affected by any cognitions, whether about it or not, of the man to whom it is external. Exaggerate this, in the usual philosophical fashion, and you have the conception of what is not affected by cognitions at all. (CP 5.525)

You may not see at first how this bears on exposing the deep confusion of Rorty's reading of Dewey and of pragmatism in general, but there's a clue there that should assist us in returning our conception of pragmatism to its true. (When I say, "its true" in this context, I intend the remark to be treated genealogically, that is, with an eye to the same conjectural future that Rorty, however inaptly, is guessing at.) Peirce has in mind Kant's confusion about the Ding an sich and the meaning of an "independent" but not noumenal world: that is, the indissolubility of the metaphysical and epistemological (which, thus far at least, is itself a valid Kantian commitment). Peirce also has in mind the entire arbitrary (indemonstrable) apparatus of Kant's transcendental reasoning, which obliges Kant to make substantive claims about the noumenal itself: especially

4. I bring the account of Peirce's fallibilism up to the more or less settled thesis of infinite Hope (which fiddles unproductively with the use of infinitesimals), in Margolis (2012: Chapter 2). I'm pressing beyond that limitation here (and elsewhere) 
about the disjunction between the apriorist and the empirical that he cannot vouchsafe. This, precisely, is what it is to be a "confused pragmatist".

What I see this leading to is the strategically important conjecture that the entire philosophical agon of our time is captured by the notion that pragmatism and Kantianism are irreconcilably incompatible - wherever the functional adequacy of Kant's apriorism is said to be strongly separable from, and opposed to, that of the empirical sources of cognition (however generously construed). Indeed, an ardent and sizable part of contemporary philosophy is bent on recovering some form of residual transcendental reasoning committed to the intent of Kant's original disjunction: whether involving the noumenal, necessary synthetic truths, the ineluctability of substantive invariances of the regulative sort, knowledge of what is real but not empirically accessible, or (ultimately) the rigor of Parmenidean thought. (I offer in evidence the views of figures like Cassirer, Habermas, McDowell, Korsgaard, possibly Rawls, possibly Brandom, quarrelsomely Davidson and Hempel).

I must add to this the very large - admittedly contentious - claim that the entire thrust of pragmatism is (or is bound to be increasingly) to repudiate anything more or less congruent with the Kantian notion of the synthetic a priori or anything in the way of strictly necessary or exceptionlessly universal or assuredly essentialist truths about the world - in a sense primarily addressed to metaphysical, epistemological, or methodological issues. The point is that Kant was quite splendid in exposing the indefensible rationalist and dogmatist invariances of his own world, but failed, egregiously, to disallow their resurgence (ingeniously altered) in his own philosophy.

The drift of modern and contemporary philosophy - progress, if you insist - is bent on defeating the final vestiges of Kantianism (and its allies in this regard). The plain fact is that even the brief picture of Dewey's thesis and testing (faute de mieux) the adequacy of flux over invariance in the indissoluble unity of epistemology and metaphysics that I've provided shows, unmistakably, that it would be impossible to accommodate any literal version of the Kantian a priori within Dewey's account. I have, separately, tried to show that, although Peirce was indeed entangled (through most of his life) with some form of Kantian aspiration, he avoided any explicit apriorism by virtue of his doctrine of infinite Hope - which, I'm now persuaded, is (and was) a failed concession to an "Idealist" commitment that he began (dawningly) to replace, very probably under the effect of pondering Josiah Royce's criticism of his infinitist fallibilism and his (seemingly more moderate) late reading of the intent of Dewey's argument (though there's every reason to believe Peirce was as much appalled by Dewey's weakness in matters of logic and science as he was by what he took to be James's conceptual carelessness). None of this is touched on by Rorty or by those Rorty influenced, though I think it would be entirely reasonable to regard Wittgenstein and Heidegger at least as open to treating the complexities of human knowledge and understanding as harboring puzzles that could not yield to the Kantian account of judgment. This part of the argument needs to be supplied. 


\section{II}

I'm persuaded that the tale I've been pursuing has a deeper import that Rorty is perfectly aware of but obscures. I cannot see how Rorty's repudiation of canonical philosophy - preeminently epistemology and metaphysics (and what, favoring "linguistic philosophy", provides the conceptual fuse of Philosophy and the Mirror of Nature) could possibly have been judged plausible at all, except in terms of the ineluctability of the so-called self-refuting paradoxes of the infinite regress of the epistemological search for the ultimate grounds of evidentiary objectivity. Kant is quite confident (in the first Critique) that the regress is "vicious" only for the "stupid" who do not grasp the force of Kant's own transcendental solution: which, of course, quite incidentally, exposes the dilemma confronting clever "Kantians" tempted to "aposteriorize" the a priori (along such lines as have attracted figures like Cassirer and C. I. Lewis). Kant believes he's outstripped skepticism by his own devices. Rorty, who is a skeptic (at least in the Greek sense), treats Kant's epistemology as one of the exemplars of epistemology's inevitable failure. But, as far as I can see, Rorty never demonstrates that the self-referential paradoxes of epistemology - which I'm entirely willing to concede - count, for that reason, as disallowing epistemology as such! What I see, rather, is that Kant's apriorist reading of his own "Copernican revolution" is intended to defeat the vulnerabilities allegedly generated by the epistemological question.

It's true, of course, that Kant was unable to confirm the validity of his apriorist method - hence, unable to defeat the concession that a reflexive epistemological skepticism was inescapable. But if we concede that the force of that linkage already belongs to Kant's transcendental reading of "first philosophy", then it becomes entirely reasonable to consider that the paradoxes may also be epistemologically benign: that is, perfectly compatible with the continued pursuit of epistemological issues $^{5}$. To my eye, this is the only possible (and plausible) resolution that does not scuttle epistemology completely.

Here, a double lesson suggests itself: first, that Dewey's argument (in Logic and Experience and Nature) heeds the lesson of Kant's "Copernican" revolution, that is, Kant's prioritizing epistemology over metaphysics even as Kant renders epistemology and metaphysics inseparable and effectively retires any and all readings of rationalism and dogmatic philosophy, including his own; and, second, that Dewey (also, Peirce, though along different lines) captures an essential piece of the pragmatist argument that turns Kant's “therapeutic" strategy against Kant's own apriorist variant, though, now, under the colors of a broadly "Darwinian" treatment of "primary experience", which also confirms Peirce's verdict that Kant is, finally, a "confused pragmatist", whether or not he could have anticipated the ineliminably inchoate features of human cognition and understanding.

5. Here, I'm persuaded that Barry Stroud's excellent reflections on the benign standing of the skeptical challenge (that is, that [Greek] skepticism probably cannot be completely defeated by any secondorder strategy, but [also] need not be defeated, if philosophical inquiry is to remain viable) confirms the reasonableness of taking skepticism and epistemology to be entirely compatible. See Stroud 2000 
The decisive consideration points to pragmatism's future: both Dewey and Peirce, in different ways, are drawn to the "empirical" (the Darwinian and post-Darwinian) need to recognize that the analysis of knowledge (a fortiori, of science and practical know-how) cannot fail to acknowledge the bio-cultural dependence of all discursively explicit processes of discovery, conjecture, inference, interpretation, judgment, confirmation and the like on unknown, inchoate, tacit, vague, indeterminate, organismic, inexplicit but undoubtedly actual factors needed to gain the exemplary successes of any explicit system of science or practical know-how. So epistemology is undoubtedly insuperably informal and conceptually incomplete.

Accordingly, I treat Dewey's efforts at sketching the holist range of his use of "experience" (already briefly summarized) as heuristic (or mythic) attempts to recover the profoundly conjectural, passing, constructivist nature of what we should mean by cognition and reflexive understanding (which extends, in Dewey, to what he himself calls "noncognitive" - itself a misleading characterization - also "organic" or "organismic". Peirce, I'm prepared to argue - and have argued, elsewhere approaches the matter more perspicuously through a strategy that (I believe) he began to see the full force of only dawningly, toward the end of his life - in what I call his "abductive turn".

This is not the right occasion to explore Peirce's strategy. But perhaps I may say that (as I see matters) Royce (who is vulnerable enough in the defense of his own theories) does effectively expose the paradoxical "Idealism" of Peirce's infinitist fallibilism (the need for an "absolute" cognizing agent, to make sense of the pragmatist force of the fallibilist formula itself). Peirce seems to stonewall on the issue; but he does also turn slowly but surely to the remarkable economies of the abductive turn, as well as (I surmise) to the intent of Dewey's line of reasoning, which (as I say) also focuses on the inexplicit, even nondiscursive features of judgment (that is, of what would be inexplicable in terms of what Kant calls "judgment"), construed as finally determinate, or determinately analyzable.

It's Kant's insistent advocacy of the conceptual transparency of discursive judgment (as both cognizing process and cognitive achievement) that falls to the pragmatist rejoinder (a conjunction, at its best, of Deweyan and Peircean counterproposals). It's easy enough to see that if the strictest transcendental resources remain unsecured (neither defended nor defensible), then if the Darwinian-inspired analysis of cognition (à la Dewey and Peirce) obliges us to admit the profoundly conjectural nature of cognition itself (quite apart from the challenge of skepticism and regress arguments), then, for one thing, pragmatism will have gained the right to claim to have advanced an early (but entirely reasonable) "final" resolution of the question of Kantian apriorism and of all similarly privileged (discursively, completely articulable) forms of science and practical understanding; and, for a second, we will have made a great advance against the presumption that epistemology must rest on some form of necessary synthetic truths (unconditional invariances, essences, and the like). For example, we should be able (as we already are) to be entirely hospitable to arguments that reject the need for invariant and exceptionless "laws of nature"6.

6. For illustrative purposes, see Cartwright 1983 and 1999. 
You cannot fail to see that, thus construed, the pragmatist argument - already among its classic figures, but insufficiently noticed there - bids fair to reverse the pendulum of Western philosophy, from Parmenides on, through Kant's "revolution", down to our own day. There's the sense in which the agon involving pragmatism and Kant (and the Kantians) proves to be more than a local skirmish. It argues the complete reversal of the main thrust of Western philosophy through the whole of its history, proceeding step by step from Plato's and Aristotle's essential compromise with Parmenides down to Kant's ingenious (but inherently flawed) effort to secure the main lines of Plato's compromise, suited, by altogether novel means, to Kant's defeat of what he took to be the then-reigning models of invariance and certitude: the continuum, now, of the explicitly cognitive and of what remains (and may, in some measure, always remain) incompletely discernible (ineliminable) in cognitional processes. It argues the essential informality of epistemology (a fortiori, of metaphysics and methodology), which need not (to be sure) be read as disallowing the would-be perceived "necessities" of any explicitly discursive analysis of science and practical understanding. (Cassirer's treatment of the need for "regulative" necessities - bearing on modern physics - provides a knockdown example. ${ }^{7}$ ) But it also means that Dewey defeats Rorty "textually" - that Rorty does not see the deeper objective of the pragmatist movement. I should add that many who are sympathetic to the pragmatist cause (very possibly including the Peirce of infinitist fallibilism, but not Dewey himself, in spite of widespread dissatisfaction with Dewey's mode of argument) ${ }^{8}$ have failed to grasp the radical possibilities of the "Darwinian" thrust of its best forays. (They regularly chide Rorty, but they have also failed to grasp how completely Rorty has failed to fathom pragmatism itself. This finding has another application that I shall come to shortly).

\section{III}

I must add, in closing, several bits of loosely linked arguments that would require a considerable run of space to be joined properly to the discussion just completed. The one decisive issue I've all but omitted concerns Peirce's abductive turn. My sense is that it's Peirce's rather than Dewey's treatment of the inexplicit - more exactly, the incompletely explicable - nature of cognition (Peirce's notion of abductive "guesses" at fruitful lines of inquiry and argument) that is likely to provide the essential nerve of the ultimate defeat of Kant's all-too discursive treatment of judgment and its executive role in science and understanding 9 . Post-Darwin, the analysis of cognition (together with the self-referential paradoxes of epistemology) is bound to yield to vagueness

\footnotetext{
7. See Cassirer (1957: 475-479).

8. For an up-to-date specimen, see the running account of Dewey's contribution, in Misak 2013.

9. Quite unexpectedly, the argument counts decisively against John McDowell's attempt to revive a very strong form of the discursivity account of perceptual knowledge, in McDowell's Woodbridge Lectures. See McDowell (2009, Part I). I've presented my analysis of Peirce's treatment of abduction (still unpublished) in a symposium commemorating the centennial of Peirce's death, in March 2014, at the annual meeting of the Society for the Advancement of American Philosophy, Denver, Colorado.
} 
and indiscernibility. But my present purpose is to give no more than a hint of the larger scope of the argument I've broached.

First, then, an addition to the assessment of Rorty's philosophical contribution as a pragmatist critic of classic pragmatism and general philosophy; and, second, a better sense of the problematic nature of Davidson's "linguistic method". Philosophy and the Mirror of Nature represents the high point of Rorty's commitment to the seeming adequacy of the form of "linguistic philosophy" he once championed, chiefly in the company (and somewhat risky tutelage) of Donald Davidson - on the assumption of the separability of "grammatical" and "epistemological" analyses: the so-called "pure" and "impure" forms of linguistic philosophy - practiced, disjunctively (so Rorty would have us believe) by Davidson and Hilary Putnam respectively. (Rorty signals his allegiance to Wilfrid Sellars as well, to the extent that Sellars's studies can be drawn in Davidson's purist direction.) The fact is, Philosophy and the Mirror of Nature is itself the expression of an actual philosophical practice, though Rorty's conclusions belie the fact ${ }^{10}$.

The point to bear in mind is that Rorty's critique of Dewey's epistemology is premised on his (Rorty's) adherence to something akin to Davidson's “pure" version of linguistic philosophy. My rejoinder to all this is simply that, for one thing, Rorty goes astray regarding the would-be disjunction, quite apart from the import of Davidson's utterly surprising essay, "A Nice Derangement of Epitaphs", which, taken literally, completely repudiates the possibility of any formalized version of linguistic philosophy along the lines of the Quinean, Tarskian, and Hempelian cast of Davidson's early papers on language ${ }^{11}$. That there is not, and cannot be, any such disjunction in Davidson's oeuvre follows directly from any cursory reading of Davidson's papers, "Radical Interpretation" and "A Coherence Theory of Truth and Knowledge".

Beyond a clarification of Davidson's actual views, we must also, thirdly, bear in mind that Rorty himself, after having published the very carefully organized collection, The Linguistic Turn (1967), which does not include any of Davidson's papers, repudiates the entire undertaking, in his "Twenty-Five Years After" piece, which he includes in the 1992 second edition of the collection. Here, without comment (or the need for comment), is Rorty's confession of the utter collapse of the very idea of a "philosophy of language" - hence, therefore, the collapse of the distinction between "pure" and "impure" philosophy of language, hence (also) the ground for the critique (or misreading) of Dewey's treatment of "experience", hence then as well Rorty's distortion of the entire thrust of pragmatism:

10. The center of Rorty's discussion of these matters, which counts as the second focus of the 1979 book (the first focus appears in Chapter 4) appears in Chapter 6.

11. Davidson's “A Nice Derangement of Epitaphs" appeared originally in LePore 1986. Rorty's own (well-known) paper in the same collection, "Pragmatism, Davidson and Truth", is a strenuous attempt to present Davidson's "purism" as a pioneer form of pragmatism, which (in fact) Rorty brings to bear on both Dewey and Peirce - more congenially (but inaccurately) on Dewey as anticipating Davidson. See, especially, Rorty's “pragmatist” summary of Davidson's commitment (1979: 335). This, of course, "explains" Rorty's "advice" to Dewey to abandon the notion of "experience" in favor of "discourse", by the time of the 1979 book. 
The idea that philosophical problems can be dissolved by detecting the "logic of our language" already seemed to me, in 1965 , untenable. But I was still, alas, attached to the idea that there was something called "linguistic method in philosophy". I now find it impossible to isolate such a method - to specify a procedure of inquiry (a "logical" or "linguistic" as opposed to a "phenomenological" or "ontological" procedure) which distinguishes a late Wittgenstein from early Heidegger or Davidson's Inquiries into Truth and Interpretation from Dewey's Experience and Nature. ${ }^{12}$

I think it not in the least unreasonable to take the original advocacy of the "linguistic turn" as Rorty's final attempt to advance a minimalist view of canonical philosophy; with its repudiation, Rorty turns to what has been called his "postmodern" pragmatist extreme. But then the new vision is no more than an autobiographical confession: it completely lacks an argument. Now, it also happens that Davidson's extraordinarily direct, uncompromising attack on Quine's extremely influential thesis, known as "radical translation", which, in my opinion, is decidedly problematic - though not for the reason Davidson advances - is itself (I mean, Davidson's substitute thesis, which he calls "radical interpretation", in a 1983 article identically thus titled) demonstrably incoherent ${ }^{13}$.

That Quine's thesis is both defective and question begging, that Davidson's counterproposal is incoherent, that Rorty's own venture with the philosophy of language came to seem to Rorty himself to be utterly lacking in philosophical purpose, constitute a remarkable state of affairs: if true, then surely we face a philosophical collapse of a very large sort. But what I want to make clear is that, bearing in mind Davidson's run of papers in the philosophy of language, Rorty's best-known efforts, in embracing Davidson's version of the "linguistic method in philosophy", are: (a) illadvised, (b) inaccurately characterized, (c) incompatible with the putative disjunction between the "pure" and "impure" forms of linguistic method, (d) impossible to be shown to be coherent or viable, and (e) mortally challenged by Davidson himself. I can't think of a comparable disaster in Anglo-American pragmatism, analytic philosophy, or "analytic pragmatism" during the second half of the twentieth century and a little more than the first decade of the new century. But it more than suggests the need for a review of all of Rorty's philosophical appraisals, and a reassessment of our true philosophical prospects from here on out.

If Davidson was right to read Quine's thesis as a petitio (I'd say he was right), though the solution offered in "Radical Interpretation" is incoherent - where Quine, despite being seriously mistaken, cannot be said to have advanced an incoherent position and if the essential thesis of Davidson's paper (and of the rest of the pertinent papers in Inquiries into Truth and Interpretation) do not sustain any disjunction between a "grammatical" and an "epistemological" treatment of language, then objections (a)-(d), against Rorty, will have been suitably addressed. We would see at once that

12. Richard Rorty, "Twenty-Five Years After”, in Rorty (1992: 373); see, also, Rorty’s original "Introduction".

13. See Davidson 2000. Davidson blunts the charge rather deftly but without effect (2000: 129n3), since the force of his own account is that Quine's thesis is a petitio. Quine's thesis appears in Quine (1960: Chapter 2). 
the mischief of Rorty's analyses of philosophical arguments extended to much more than pragmatism narrowly construed. In fact, the collapse of Davidson's program of linguistic analysis may be even more worrisome, precisely because Davidson (quite correctly) intends his own work to be read as committed to canonical philosophical objectives. Very possibly, the most important paper in the Inquiries volume, "On the Very Idea of a Conceptual Scheme" (1974), is, I'm prepared to say (but won't argue the matter here) based on a demonstrably mistaken reading of Thomas Kuhn's immensely disputed notion of a "paradigm shift", though through it all Rorty's (as well as Davidson's and Sellars's) "linguistic method" ranges freely, without special provisions of any sort or any division between "pure" and "unpure" considerations. The charge of item (e), which marks a fundamental change in Davidson's speculations about language, appears in a novel (but completely autonomous) way in "A Nice Derangement of Epitaphs", though the paper is not included in the Inquiries volume and cannot be treated as "postmodern" in Rorty's way (though Rorty's and Davidson's "methods" overlap in spite of that).

These remarks about Davidson's "linguistic method" have, admittedly, very little to do with the right analysis of Dewey's pragmatism, except that Davidson's account of "radical interpretation" is (and may be seen at once to be) unconditionally incompatible with any plausible form of pragmatism. (This is emphatically not true of Quine's problematic notion of "radical translation".) Furthermore, Rorty's elevation of Davidson, as very possibly the single most important "pragmatist" voice among the cohort following Dewey's death (to include figures like Quine, Sellars, Putnam, Kuhn, and, much later, Brandom) betrays the unreliability (possibly, the sheer opportunism) of Rorty's appraisal of these admittedly important figures. Rorty, I suggest, obliges us to pause long enough to consider what rightly serves to define the pragmatism of our own day: it must yield ground in the direction, say, of Wittgenstein and even Carnap, but (I would say) nothing in favor of Davidson's "method".

I regard the following line of reasoning to capture the essential premise of Davidson's "radical interpretation" thesis - and to betray, at the same time, its utter incoherence:

radical interpretation, is supposed to supply an understanding of particular utterances that is not given in advance, so the ultimate evidence for the theory cannot be correct sample interpretations. To deal with the general case, the evidence must be of the sort that would be available to someone who does not already know how to interpret utterances the theory is designed to cover: it must be evidence that can be stated without essential use of such linguistic concepts as meaning, interpretation, synonymy, and the like. ${ }^{14}$

The truth, I venture to say, is just the reverse of what Davidson claims here! (But the supporting argument and rationale are needed.) Davidson finds (correctly) that Quine's "radical translation" thesis favors construing the apparent verbal behavior of an alien speaker in terms of our own language. But how can we confirm that we

14. Davidson (2000: 128). See the heroic effort to recover Davidson's thesis, in LePore and Ludwig 2005 , considered in the light of their verdict in the final paragraph: "impossible" (424). 
know the meaning of the counters of our own language? Here, Davidson has no wish to deny that apt speakers do know their native language: it's only that we must ask ourselves how, in principle, can we show that we understand the meaning of our words? The answer, according to Davidson's scruple, is that the evidence must be drawn entirely from behavioral data that do not draw (in any way) on "correct sample interpretations" (of linguistic meaning) - because to proceed thus would be to proceed by petitio.

Davidson is right, of course. Nevertheless, he is urging the impossible. The counterargument does not depend on either the "pure" or "impure" strategies Davidson lays out: it depends, rather, on the preconditions of either or both, if either or both is viable at all. And, of course, the intent of the argument overrides the fatal disjunction Rorty has put his trust in: it presupposes, first, that if the originating question makes sense (it does make sense), then there must be a valid answer to the question (which is either an equivocal judgment or demonstrably incapable of relieving the original petitio). That's to say: the question cannot be answered without drawing us back to the puzzles of Kant's "revolution" of first philosophy, which appear (thus transformed) as the self-referential paradoxes of epistemology.

The solution I favor accepts, you will recall, the benign compatibility of skepticism and the effective resolution of the epistemological paradoxes - on the premise that, post-Darwin, evidence of a suitable form of cultural immersion is the only conceivable way of providing evidence of linguistic mastery. But that of course disallows any solution of Davidson's sort: the admission of the unique, artifactual invention (and subsequent serial mastery of language among the infant members of the species) provides the normally adequate (effective) evidence of our knowledge of meanings. My own line of argument holds that, on the paleoanthropological evidence, the original invention and serial mastery of language is the verso of the artifactual formation of the human "person" or "self", the self-transformed human primate, the fully functional human subject or agent, whose very existence is inseparable from the societal sharing of a language ${ }^{15}$.

Hence, in one stroke, we glimpse the impoverishment of both Davidson's and Rorty's philosophical programs; an essential contribution to the defeat of Kant's own premise in favor of the necessity of a transcendental solution to the epistemological question; the dawning significance of Dewey's and Peirce's attenuation of the theory of knowledge along the lines of the tacit, the indeterminate, the thoroughly fluxive, the informal, the inexplicitly organismic, the inchoate; and the natural advantage (contra Kantian and analogous necessities) of the deepest pragmatist strategies. Apparently, there is no place for such conjectures in either Davidson or Rorty (pace Davidson's "A Nice Derangement" and Rorty's "Twenty-Five Years After"). We cannot fail to see that both neglect the obvious way out.

The reductio of Davidson's thesis (in "Radical Interpretation") may be put this way: on the Darwinian and post-Darwinian paleoanthropological evidence, "natural language" is itself a contingent cultural invention of Homo sapiens. To admit the

15. For a brief glimpse of the theory of persons, see Margolis (2012: Chapter 3). 
fact is to admit the need for a novel form of evolution - to accommodate the nonstandard features of the human career: the hybrid intertwining of the biological and the cultural; the uniquely complex, specialized neural circuitry of the human brain (suited to the gradual invention, societally reliable transmission, and socially enabled individual acquisition, of language itself); the paradoxically helpless, totally dependent, prematurely birthed, evolutionarily ill-adapted, possibly even regressively disadvantaged, post-natal biological development of the infant primate members of the species; the remarkably acute, compensatory sociability and aptness for social play and specifically encultured (and enlanguaged) learning on the part of human infants; and the effective identity of the double Bildung involving language, namely, that of the longitudinal invention (over an immensity of time) of true language and the serial mastery of language by successive cohorts of primate infants; and the transformation (the self-transformation) of the primate members of Homo sapiens into functional selves or persons.

In effect, the thesis of the hybrid artifactuality of persons is (in my opinion) the most plausible account of the prehistorically dated cultural achievement of the invention and functional fluency of human speech that we possess. I emphasize the inseparability of our understanding the unique features of speech and language and their biological and cultural sources: because, in that way, we are led to grasp the full force of the premise that we cannot possibly explain our understanding the meaning of what we say (in speaking a language) except in terms of the unique forms of cultural immersion by means of which the trick is turned! We literally cannot suppose that linguistic competence and understanding speech can be confirmed (the gist of Davidson's challenge to Quine) by any form of behavioral, animal, or machine intelligence that is not itself suitably informed linguistically. The achievement of language depends on capacities (that are themselves culturally acquired) that, though materially enabled (normally by means of conventionally ordered sounds and gestures) are said to yield "meaningful", transformed counters (words and sentences, as we say) - counters capable of "conveying meanings" - that only human persons (or suitable surrogates) can rightly manifest. Philosophically, the emergence of language appears to provide the best evidence against every known form of physical reductionism.

There's room here for any sort of theoretical fine-tuning that may be needed. We signal the uniqueness and irreducibility of the linguistic to any other form of meaningful communication by its functional features - say, by reference to its "symbolic" and "symbolizing" structure (as, for instance, in accord with Peirce's semiotic or something akin). But, if conceded, then Davidson's proposal will be seen to be incoherent - in supposing that linguistic meaning can be captured by behavioral (or other) resources that, however "meaningful", utterly lack language's unique way of conveying meaning. If you concede all that, then you must also see how impossible it becomes to deny that the self-referential paradoxes of our claim to understand linguistic meaning (or to know what knowledge is, or to confirm, reliably, that we know what we claim to know about language and the world) must be benignly circular and benignly vulnerable to skeptical challenge. There's the evidence that the distinctive doctrines of Davidson, Rorty, and Kant regarding knowledge are flatly indefensible. 
I have a last bit to add. I cited, early on, a passage from Dewey in which he speaks of "the large and constant features of human sufferings, enjoyments [and the like] together with the institutions of art, science, technology, politics and religion". I take Dewey to be saying, here, that his sort of pragmatism makes pointed provision for all the existential concerns that belong to the "logic of inquiry", in the sense in which inquiry takes precedence over canonical logic or science, but in the sense (also) in which the theorizing concerns of art, science, and practical life equally belong to the primary concerns of "inquiry" - in fact, the sense in which, without the existential linkage between the "two" sorts of involvement mentioned, any concern that "sufferings and enjoyments" will be appropriately served may not be effectively satisfied. Both Dewey and Peirce are absorbed (in very different ways) with the continuum of inquiry. I'm persuaded that our grasp of the artifactuality of the human person (the hybrid, biologically and culturally ramified emergence of the human person) is, in fact, the single most important conceptual discovery about human life itself (including our understanding human sufferings and enjoyments); so that, for many reasons, there cannot be any effective priority between the existentialia of human feelings and those of our reflexive conception of the human condition itself!

I mention the effective inseparability, philosophically, between human "experience" (however parsed) and an adequate conception of human experience, because of a rather odd (but well-meant) criticism - adventitiously directed against me (which, if valid, would serve in a perfectly freestanding way). The charge appears in a review by Douglas Browning, of an earlier book of mine, Historied Thought, Constructed World (1995), written without specific reference to Dewey's Logic and Experience and Nature (though certainly influenced by pragmatist inclinations). I mention Browning's review because it makes a very strong claim about the proprieties of "where" one "begins" (or should begin) - where one "enters" the discussion, so to say - in beginning a responsible philosophical affirmation, and because it has been seconded by qualified readers loyal to pragmatist concerns. Here is Browning's charge:

To start with symbiosis [that's to say, with my advocacy of the indissoluble unity of metaphysics and epistemology], even holistically understood, is to start with a theory, and to start with a theory is to start by assuming a certain cognitive privilege. But Dewey is as insistent as Margolis that no such privilege is warranted. Dewey's starting point is pre-theoretical; Margolis's is not. ${ }^{16}$

16. Browning (1997: 183). I'm persuaded that Browning's charge deserves an answer, partly at leas because David Hildebrand has pressed the need for an answer, in several papers, both without and with reference to my own way of proceeding. See Hildebrand 2011. Hildebrand refers to Dewey's "starting point" as "noncognitive" (53): he means that Dewey begins with the "stuff" of "primary experience", that is, of "experience" that is not captured by prior, so-to-say already antecedently "finished" theories. I see the intended distinction clearly enough. But I don't see how the "givenness" of primary experience (in the sense intended) is not, also, a theoretical posit of "something" intended to be not theoretically structured by any antecedent theory! Browning speaks of this as "pre-theoretical". I have no difficulty with the claim, but I must insist that it requires (and is inseparable from) a theorizing provision that what it "denotes" is "pre-theoretical"! Now if that's admitted, then I don't see how the force of Browning's charge can be made to depend on the fact that I support the "symbiosis" of metaphysics and epistemology; or to deny that what is "denoted" (in Dewey's special sense) as "pre-theoretical" is (also) robustly posited by an initial theory. I also don't see how the descriptive 
I'm afraid I find Browning's charge to be either irrelevant or entirely caught up in a fruitless equivocation. I see no difficulty in conceding that one may posit (by way of a sympathetic theory) a "pre-theoretical" - an uncognized but organismically "suffered" - state or feeling, unqualified by any antecedently posited theory on which its characterization depends. But if one goes this far, then, I suggest, one must have the courage to oppose the idea that we can assuredly provide the accurate characterization of that "given"; for, otherwise, that "given" will not fail to be privileged. (My suggestion is that Dewey must be speaking heuristically - or "mythically" - here.)

Consider a loose analogy: logical theory, applied to the analysis of naturallanguage sentences, posits, benignly, the existence of atomic sentences; but it cannot provide an instance of a natural-language atomic sentence, though it makes use of the idea in all its pertinent applications. Browning, I'm afraid, has missed the point of Dewey's thesis. Davidson can't be a pragmatist, inasmuch as he champions the executive claim of "Radical Interpretation". But he could have abandoned the idea. And Rorty was a "confused pragmatist" at best, during the time he believed Davidson's "linguistic method of philosophy" (which relied on the force of essays like "Radical Interpretation" and "The Very Idea of a Conceptual Scheme") constituted a pragmatist advance of the first rank. I don't see the relevance of Browning's argument in my own case.

\section{References}

Browning D., (1997), "Review of Joseph Margolis, Historied Thought, Constructed World", Southwest Philosophical Review, 13, 177-184.

- (1998), "Dewey and Ortega on the Starting Point", Transactions of the Charles S. Peirce Society, 34, 69 - 92.

Cartwright N., (1983), How the Law of Physics Lie, Oxford: Clarendon.

- (1999), The Dappled World: A Study of the Boundaries of Science, Cambridge: Cambridge University Press.

Cassirer E., (1957), The Philosophy of Symbolic Forms, volume 3, trans. by Ralph Manheim, New Haven: Yale University Press.

Davidson D., (1986), “A Nice Derangement of Epitaphs”, in Truth and Interpretation: Perspectives on the Philosophy of Donald Davidson, ed. by Ernest LePore. Oxford: Basil Blackwell.

terms, "sufferings" and "joys" can be the proper "denoting" terms of what is said to be "given" pretheoretically: no description can serve (except mythically). See, also, Browning 1998. I should add that Browning's objection is, on my view, incompatible with Dewey's own statement, cited (above) from Dewey's "Half-Hearted Naturalism". 
Davidson D., (2000), "Radical Interpretation", in Inquiries into Truth and Interpretation, Oxford: Clarendon, $2^{\text {nd }}$ ed.

Dewey J., (1927), “Half-Hearted Naturalism”, Journal of Philosophy, 24, 3, 57-64.

— (1938), Logic: The Theory of Inquiry, New York: Holt.

- (1981), Experience and Nature, in The Later Works, volume 1, ed. by Jo Ann Boydston, Carbondale, IL: Southern Illinois University Press.

Hildebrand D., (2011), “Could Experience Be More than a Method? Dewey’s Practical Starting Point”, in Pragmatist Epistemologies, ed. by Roberto Frega, Lanham: Lexington Books.

LePore E. and Kirk L., (2005), Donald Davidson: Meaning, Truth, Language and Reality, Oxford: Oxford University Press.

Margolis J., (2012), Pragmatism Ascendent: A Yard of Narrative, A Touch of Prophecy, Stanford: Stanford University Press.

McDowell J., (2009), Having the World in View: Essays on Kant, Hegel, and Sellars, Cambridge: Harvard University Press.

Misak C., (2013), The American Pragmatists, Oxford: Oxford University Press.

Murphy A. E., (1951), “Dewey’s Epistemology and Metaphysics" [1939], in The Philosophy of John Dewey, ed. by Paul Arthur Schilpp, New York: Tudor.

Peirce C. S., CP, (1962), Collected Papers of Charles Sanders Peirce, volume 5, ed. by Charles Hartshorne and Paul Weiss, Cambridge: Harvard University Press.

Quine W.V.O., (1960), Word and Object, Cambridge: MIT Press.

Rorty R., (1979), Philosophy and the Mirror of Nature, Princeton: Princeton University Press.

— (1982), Consequences of Pragmatism: Essays 1972-1980, Minneapolis: University of Minnesota Press.

- (1991) Objectivity, Realism, and Truth: Philosophical Papers, volume 1, Cambridge: Cambridge University Press. 
Rorty R., (1992), “Twenty-Five Years After”, in The Linguistic Turn: Essays in Philosophical Method, Chicago: University of Chicago Press, $2^{\text {nd }}$ edition.

Stroud B., (2000), "Taking Skepticism Seriously", in Understanding Human Knowledge: Philosophical Essays, Oxford: Oxford University Press. 